https://helda.helsinki.fi

\title{
Nominalism and the Via Moderna in Luther's Theological Work
}

\section{Kärkkäinen, Pekka Antero}

Oxford University Press

2017

Kärkkäinen , P A 2017 , Nominalism and the Via Moderna in Luther's Theological Work . in D R Nelson, P R Hinlicky , L Malcolm , M L Mattox , R Saarinen , A Vind \& J Zachhuber (eds) , The Oxford Encyclopedia of Martin Luther . vol. 2 , Oxford Research Encyclopedias, Oxford University Press , Oxford , pp. 696-708 . https://doi.org/10.1093/acrefore/9780199340378.013.266

http://hdl.handle.net/10138/225762

https://doi.org/10.1093/acrefore/9780199340378.013.266

acceptedVersion

Downloaded from Helda, University of Helsinki institutional repository.

This is an electronic reprint of the original article.

This reprint may differ from the original in pagination and typographic detail.

Please cite the original version. 


\section{Nominalism/Via Moderna}

Pekka Kärkkäinen

This is a draft of an article that has been accepted for publication by Oxford University Press in the Oxford Research Encyclopedia of Religion.

\section{Summary}

Luther began developing his theology within the late medieval school of the via moderna (also called the Nominalists). This school of thought had developed during the $15^{\text {th }}$ century mainly as a method for interpreting Aristotle, which relied on certain $14^{\text {th }}$-century authorities, such as William of Ockham, John Buridan, Gregory of Rimini, and Peter of Ailly among others. Luther studied philosophy according to the via moderna in Erfurt, where his teachers Jodocus Trutfetter and Bartholomaeus Arnoldi of Usingen represented a position, which tolerated the Thomist and Scotist views. The school also featured a specific kind of theology, which was based on its interpretation of Aristotle. Among the most influential theologians in the German via moderna was Gabriel Biel in Tübingen, whose theology was crucial for Luther's understanding of the school's positions. Besides Ockham, whom Biel mentioned as his main authority in his Sentences commentary, Biel adopted the positions of several other authors, even outside the common authorities of the via moderna. Other influential theologians and philosophers affiliated with the via moderna were John Mair in Paris and John Eck in Ingolstadt. Later both became adversaries of Luther and the Lutherans, as did Luther's former teacher Usingen. The University of Wittenberg did not host the via moderna at all. Thomist and Scotist forms of the via antiqua were predominant among its academics, including the later Reformer Andreas Bodenstein of Karlstadt. During his early years as a student in Erfurt, Luther remained largely among the camp of the via moderna. Soon after moving to Wittenberg, Luther developed his criticism of Aristotle and late medieval theology, where his main target was 
that of Biel's theology, and especially his doctrine of grace. However, even during those years Luther retained much of his scholastic education, including an interpretation of Aristotle, in which he adopted several of Ockham's ideas. Even during his later years, Luther made use of terminological tools of the via moderna, even when opposing some of its theological positions.

\section{Keywords}

via moderna, Nominalism, scholasticism, Gabriel Biel, William Ockham, grace

\section{Introduction}

Luther developed his theology within the scholastic school of the via moderna. Being educated according to this school, Luther launched his attack on scholastic theology with a deliberate criticism of the main proponent of the school, Gabriel Biel (c. 1410-1495). During Luther's lifetime this school of thought, whose adherents have also been called the Nominalists (nominales), was thought to preserve the new critical insights developed by William Ockham in the early $14^{\text {th }}$ century. This understanding has credited this school of thought also with its third major designation as "Ockhamism." This last title appears to be misleading, however, when applied to early $16^{\text {th }}-$ century thinkers, since there is no clear doctrinal continuity between the $15^{\text {th }}$-century via moderna and its $14^{\text {th }}$-century authorities. ${ }^{1}$

In modern research the view of the via moderna has changed considerably. Through historical studies it has become evident that the earlier conception of the via moderna has inherited elements, in which $15^{\text {th }}$ - and $16^{\text {th }}$-century ideas have been anachronistically projected onto $14^{\text {th }}$-century thinking. Apart from its relationship to the Lutheran Reformation discussed later below, the 
traditional understanding of the via moderna as a uniform school of thought continuing from the $14^{\text {th }}$ to the $16^{\text {th }}$ century has largely been rejected. Instead, it turns out to be a phenomenon predominantly developed in the $15^{\text {th }}$ and $16^{\text {th }}$ centuries, although heavily dependent on certain $14^{\text {th }}-$ century authorities. This applies especially to the position of Ockham as the founder of the school, whose adherents have often also been referred to as "Ockhamists." The idea of considering Ockham as the leading authority of the school derives from the $15^{\text {th }}$-century academic disputes, which took place mainly in Paris. During these disputes Ockham, who was accused of heresy, was used as an indication of the doctrinal heterodoxy of the theologians, who had adopted his views. Considering a group of theologians as followers of Ockham was part of the argumentation of their adversaries, which eventually resulted in their actual exclusion from the teaching positions in the University of Paris. Such a strategy was used for example by Thomists, who could boast that their main authority as a canonized saint. However, in their response to such accusations, also the gradually developing group of the via moderna could reciprocate in kind. That is, the group could point to the condemned John Wycliffe as an example of the direction in which the Thomist and Scotist metaphysical positions led, and could accordingly accuse them of heretical teaching. ${ }^{2}$

Several scholars of $14^{\text {th }}$-century philosophy and theology have plausibly argued that it is not possible to formulate such doctrinal uniformity between Ockham and his contemporaries and later writers, who have been identified with the via moderna. ${ }^{3}$ Nevertheless, it would be a mistake to completely deny the connection between the via moderna of the $15^{\text {th }} / 16^{\text {th }}$ centuries and its $14^{\text {th }}-$ century authorities. Seen from a perspective of the via moderna as it had developed by Luther's time, certain $14^{\text {th }}$-century writers had gained a special authoritative status. The case was similar with the followers of the via antiqua. The term "way" (via) indicated a method used among the adherent of a school. It concerned mainly the interpretation of Aristotle, and with it the main authorities used throughout the commentaries were indicated. Accordingly, among the via antiqua, 
Thomists followed Aquinas, Scotists followed John Duns Scotus, and Albertists followed Albert the Great. For the philosophers in the via moderna the case was more complicated. Their main authorities consisted of a number of more recent authorities than those of the via antiqua. The most common of these were William of Ockham, John Buridan, Marsilius of Inghen, Gregory of Rimini, and Peter of Ailly. Using particular authorities tended toward doctrinal commitments on certain issues, but a general uniformity of doctrine inside the individual schools is impossible to point out. ${ }^{4}$

\section{The Via Moderna and Luther's Studies in Erfurt}

In the University of Erfurt, where Luther studied, the via moderna formed the basis of teaching in philosophy and also in theology among the secular masters. Unlike many other universities in Germany, Erfurt had never accepted the co-existence of different schools and was therefore considered as a stronghold of the via moderna. The situation did not prevent the religious orders from teaching according to their own authorities among their own members, even by professors who were formally considered as professors of the university. Most of the professors in Luther's own order, the Augustinian Hermits, had, by the early $16^{\text {th }}$ century, been teaching theology following in the traditional authority of the order, Giles of Rome. Within the school theology, Giles would have been classified as being among the authorities of the via antiqua rather than of the via moderna. Similarily, the Erfurt Franciscans had relied in their teaching mostly on John Duns Scotus, whose adherents, the Scotists, were among the academic schools considered a part of the via antiqua..$^{5}$

In practice the university's reliance on the via moderna meant that the teaching of philosophy in the Faculty of Arts and the teaching of theology by the secular masters was carried out according to that school. There are no direct sources of the theology of the via moderna in early $16^{\text {th }}$-century Erfurt, 
but the philosophical contents of the via moderna can be traced from the works of Jodocus Trutfetter of Eisenach (c. 1460-1519) and Bartholomaeus Arnoldi of Usingen (c. 1465-1532). Luther mentions both of these as his teachers, and Usingen even became his fellow friar among the Augustinians. They were leading authorities in the Faculty of Arts during Luther's studies, but later during Luther's theological studies they had a similar position in the Faculty of Theology. From their works it is possible to delineate Erfurt's via moderna as Luther knew it, that is, in terms of authoritative sources and doctrinal commitments. ${ }^{6}$

The Erfurtians identified the via moderna with certain philosophical doctrines and authorities. This was typical of the via moderna and the varieties of via antiqua, which may even be considered as essentially philosophical in nature. However, due to the intimate relationship between philosophy and theology, the decisions concerning philosophical doctrines had a profound impact on theological doctrines, and, in reverse, the plausibility of philosophical doctrines depended on the orthodoxy or heterodoxy of their theological implications. In practice, however, the authorities that were used as a basis for teaching had more influence on the actual differences between the schools. ${ }^{7}$

Luther himself has passed down a remark, which implies that, in his time, current philosophical tradition at his alma mater originates in the earlier $15^{\text {th }}$-century author Johannes Rucherat of Wesel,

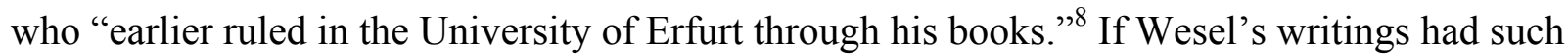
authority in the university until Luther's times, his understanding of the via moderna as a school will serve as a suitable starting point in the description of Luther's philosophical milieu.

Even before Wesel, the rejection of two philosophical positions were central in defining the philosophical tradition in the University of Erfurt. In the early fifteenth century, when Amplonius Rating of Bercka founded the influential college of Porta Coeli, two extreme positions were 
rejected: (1) a "Platonist" realism concerning universals, and (2) the plurality of substantial forms in the same subject, like many souls in one individual human being. Regarding the authoritative writers, "modern" philosophers like William Ockham and John Buridan were followed, but older authorities such as Albert the Great, Thomas Aquinas, Alexander of Hales and Giles of Rome were recommended as well. ${ }^{9}$

Wesel followed the guidelines mentioned above. According to him, there is no entity, which is by its nature universal (res universale), therefore all entities are by nature singular. Universals are concepts of the created minds, which represent many singular things. They do not exist in God, even if God has in some sense ideas of all created things in his essence. Since God is conceived as radically simple, the distinctions between different kinds of entities arises first in the human minds and not in the essence of God. Wesel's position of universals as concepts is not strictly speaking nominalist, since he also rejected the version of fictum-theory, where universals are conceived as terms created by the mind without any correspondence to the things they signify. Wesel also rejected the plurality of forms in one individual subject. ${ }^{10}$

Jodocus Trutfetter followed a similar conceptualist position as Wesel, and explicitly identified himself among the "Nominalists" (nominales). Nevertheless, he showed further understanding regarding positions that differed from his own. Trutfetter clearly rejects such a realist view, which affirms the idea of a real unity of universal natures between singular entities. He relates such a realist view to the Hussite heresy condemned by the Council of Constance. In contrast, a plausible realist position, according to him, would consider universal natures as being only potentially present in the things themselves, but becoming actual only in the process of understanding. In his reading, among the via antiqua the Thomist position follows this line, and even the Scotist position with 
certain reservations. A similar attitude towards rivaling schools can be found in Usingen's writings. ${ }^{11}$

Trutfetter's position may reflect his openness to rivaling philosophical schools, but also to his reverence to older authorities like Thomas Aquinas. As noted above, this was not unusual in the Erfurtian via moderna. It appears that Trutfetter even wrote a commentary on Aquinas's Summa theologiae, although nothing besides his own occasional reference to the work has survived of it. ${ }^{12}$ In the introduction to his major book on logic, Trutfetter reveals his attitude to different authorities. Without questioning the validity of older authorities - after all, Aristotle himself was the greatest of the school bearing his name - he defends the merits of the most recent (moderni) authors as writers, who have gathered the most comprehensive experience in their respective fields. At the same time he rebukes the writers, who rely on the holiness or old age (vetustas) of the writers, calling them more "lovers of the author than lovers of the truth."13 Trutfetter refers to a considerable number of sources in his works. Like Usingen, he mostly follows the principal authorities of the via moderna: John Buridan, William of Ockham, Gregory of Rimini, Peter of Ailly and, especially in the later works, Gabriel Biel. In addition to these, he cites favorably for example the medical treatises of Peter of Abano, Augustinian theologian Alphonso Vargas, and a contemporary compendium of philosophy by a Carthusian, Gregor Reisch. ${ }^{14}$

In addition to the questions on universals and the plurality of forms, Usingen's writings reveal some further points, which were considered by the Erfurtian authors consciously as the position of the via moderna. One of them is the principle of parsimony, sometimes also called "Ockham's razor." According to this principle, one should not presume multiplicity, if it is not necessary or without reason. For Usingen this was a metaphysical or ontological principle, in the sense of not presupposing more entities than necessary without reason. The ontological reading of the principle 
dates back to Gregory of Rimini, and like him, Usingen applied it to the rejection of the Thomist real distinction between the faculties of the soul. Furthermore, he considered that the doctrines of the philosophers of the via antiqua violated this principle, which he considered to be genuinely Aristotelian. ${ }^{15}$ Furthermore, Usingen specifies the position of the via moderna against the via antiqua on the question concerning real vs. rational distinctions. ${ }^{16}$ Concerning the epistemological issues, Usingen does not always contradict the via antiqua, but sometimes he supports the common position of the via moderna (opinio communis viae modernae) against its own authorities like Ockham and Gregory of Rimini. This is a further indication of the fact that philosophers of the via moderna did not identify themselves as representatives of a school on the basis of a strict adherence to certain authorities, but rather by way of similarities to certain basic doctrines, which they considered important. ${ }^{17}$

Since no printed theological sources of the via moderna from either Erfurt or Wittenberg during Luther's days have survived, the closest reference on the theology of the school will be found from the University of Tübingen. Among the theologians of the via moderna, Gabriel Biel (c. 1410-1495) was the one, whose writings became for Luther the most relevant. Being one of Trutfetter's and Usingen's main authorities, Luther was familiar with Biel's position in several matters through his studies in the Faculty of Arts. During the time for the preparation of his first Mass in Erfurt, Luther carefully studied Biel's commentary on the Canon of Mass. Later in the preparation of the Sentences lectures Biel's commentary on the Sentences seems to have been the most obvious reference for Luther's own comments, even if explicit references to Biel are not many. However, Luther did not depend on Biel regarding the authorities of the via moderna like Ockham or Peter of Ailly. There are even traces of textual criticism on certain of Ockham's texts from Luther's hand. ${ }^{18}$ 
As a professor of theology "according to the via moderna" in Tübingen, Biel was one of the most influential representatives of this school during his lifetime and also later through his works. Nevertheless, one should not forget that Biel was not only an academic theologian, but a highly respected figure among the Brethren of Common Life. Accordingly, his theology was not merely targeted toward academic discussion, but largely took notice of the pastoral viewpoint, too. Detlef Metz has scrutinized in his study the multiform connections of Biel's theology to the mystical tradition. ${ }^{19}$

Biel addressed a wide array of theological topics in his writings. From the viewpoint of Luther's theology, two areas appear particularly relevant: the theology of grace and the theology of the sacraments. The consideration of these doctrines elucidates well Biel's relationship to his authorities: although Ockham features as the main authority in the introduction of his commentary of the Sentences, several other writers supersede him in the discussion of individual topics. ${ }^{20}$

In his discussion of original sin, Biel consciously rejects the position shared by Ockham and Scotus, and he favors the position followed by Bonaventure and Aquinas instead. According to their position, original sin consists of both the absence of original righteousness as well as the presence of evil concupiscence. Unlike Scotus, Biel stresses that through original sin the human being is not only deprived of the original gifts of grace, but the very human nature of man is corrupted by the Fall. $^{21}$

In the discussion about the capabilities of a human being in preparing him- or herself for the reception of grace, Biel's position is ultimately based on the early Franciscan theological tradition, presented by Alexander of Hales, who insisted that all people have at all times known God in some manner, and therefore asked God for knowledge of faith and what is good. With Scotus Biel comes 
to the conclusion that it is possible for the human being to love God above all things with pure love and without the assistance of grace. This transitory act of loving God above all is for Biel the merit required from a human for the reception of grace, although its meritoriousness is based exclusively on God's divine generosity, and nothing else. ${ }^{22}$ Unlike Scotus, but in agreement with Alexander of Hales and many others, Biel states that a penitent person needs to have an act of repentance caused by love of God, and not only one based on fear of God, in order to regain grace, which was lost by actual sinning. ${ }^{23}$ Furthermore, according to Biel a person is not worthy of receiving eternal life without an infused habit of created grace or love, which unites the person with God. ${ }^{24}$

Among Luther's two Nominalist teachers mentioned above, Usingen is the only one, who published theological treatises. In addition to his published pamphlets against the Lutherans, Usingen wrote an extensive work as a response to Melanchthon's Apology of the Augsburg Confession, which has survived in manuscript form. ${ }^{25}$ Since Usingen's theological writings date from a rather late period of his life, when he was actively involved in the criticism of the Lutherans, and were influenced by Humanist reforms, these writings only indirectly witness the theology of the via moderna of Luther's study years. Even so, Usingen's theological positions followed in the footsteps of Biel, and even at such a late stage reveal some adherence to the tradition of the via moderna. These include the notion of merit, human activity in penitence, and generally the relationship between nature and grace in salvation. ${ }^{26}$

\section{Theological Schools in Other Universities}

Another contemporary philosopher and theologian worth mentioning is John Mair (c. 1466-1550).

Originally from Scotland, he spent most of his academic life in Paris. He, along with other Parisian 
scholars, wrote against Luther and the Lutherans and, at least in one case, Luther objected to a Christological position, one which can be identified from Mair's writings. Among other Lutheran Reformers, Melanchthon mentions Mair and affirms familiarity with his writings. ${ }^{27}$

Mair has often been identified with the via moderna, but due to his affinities with theologies of Aquinas and Scotus, this identification has been challenged, and he has even been characterized as eclectic. In the case of Mair, eclecticism appears as a label too easily assigned; for example, it does not take into account his deliberate efforts in bridging the obvious divide between the schools. ${ }^{28}$ Mair's early philosophical works attest to a strong affiliation with the via moderna. ${ }^{29}$ Regarding his theological works, the same applies to the early redaction of his Sentences commentary from 1516, where he openly advocates the method of the Nominalists against the accusations of the Realists. ${ }^{30}$ However, like Trutfetter in philosophy, as a theologian Mair was tolerant towards the positions of other schools. As long as their positions did not contradict Catholic doctrine, theologians were not to be blamed for choosing a particular doctrinal position. Mair even states that it is more desirable to choose an established traditional position than trying to formulate one's own. To this he added the proviso that an academic theologian should not claim the truth of one's position, but only consider it as probable. $^{31}$

However, in individual theological questions Mair ended up criticizing the Realist views, although his criticism did not so much meet their actual views than meet their conclusions, which could be drawn from their view of universals and other logical doctrines. ${ }^{32}$ At the same time, he was ready to contradict positions of the via moderna as well, like those held by Gabriel Biel. However, such criticism did not bring him any closer to Thomist or Scotist positions, but was rather an indication of a desire to reduce the complexities of scholastic analysis; an ideal, which he shared with theologians like Jean Gerson, contemporary humanists and the Protestant Reformers. ${ }^{33}$ A tendency 
to adapt himself was even more evident in the later editions of Mair's logical works. By the late $1520 \mathrm{~s}$, he gradually dropped some specifically Nominalist tracts from his works, but also the Summulae by Peter of Spain, which was used by all schools alike. Instead, he devised the textbooks as commentaries of Aristotle. Furthermore, he substituted references to scholastic authors with ancient sources and simplified the course of argumentation, still without giving up his reliance on the positions of the via moderna. Nevertheless, through these stylistic renewals his positions became more acceptable to Thomists and Scotists so that, in a way, through humanist influences, he eventually converged on the positions of the rivaling schools, also on the practical level. ${ }^{34}$

A similar development can be traced in the philosophical career of another representative of the via moderna: John Eck. Known as one of Luther's major opponents, Eck was far more involved than Mair in the humanism of his time. Eck honored Mair as a theologian, and was familiar with his Sentences commentary. Eck considered Trutfetter as the most esteemed authority in philosophical matters, although he also criticized him on several occasions. ${ }^{35}$ Eck took seriously the challenge of a humanist critique towards a barbarian style and language, especially in the books of logic. Concurrently, like Mair, he tried to gather the tradition of late medieval via moderna into his textbooks, embedding the discussions in the commentaries of a renewed humanist translation of Aristotle and furnished with the latest humanist writers. ${ }^{36}$ His references to earlier literature reveal a similar admiration for Aquinas and Scotus, which we find in Trutfetter, as well as a similar reliance on the common authorities of the via moderna.$^{37}$ Eck was, however, more critical than Trutfetter towards the late medieval Thomist and Scotist authors. ${ }^{38}$

The University of Wittenberg was not particularly favorable to the via moderna. The university statutes from 1508 mention, besides Thomism and Scotism, a via Gregorii as one of the three schools taught at the university. This has been interpreted to mean the via moderna with reference 
to Gregory of Rimini, but in practice this remained a barren letter. Trutfetter is the only person, who has been recorded as having taught according to the via moderna at Wittenberg. Even his activity, however, remained confined between the years 1506 and 1510, after which he returned to Erfurt. ${ }^{39}$ The teaching of philosophy was dominated exclusively by Thomists and Scotists. Following the model of Tübingen, the Scotist teaching relied on the textbooks of the Parisian Scotist Pierre Tartaret, whose works were printed in Leipzig already in 1503 on behalf of the first Dean of the Arts Faculty. Thomist teaching was advanced by Martin Pollich of Mellerichstadt, the first rector of the university, who came from Leipzig. Mellerichstadt had close contacts with the Thomists in Leipzig, but was educated by the leading German Thomists in Cologne. He also recruited Thomists with a similar background in Cologne Thomism, including Kilian Reuter, poet Georg Sibutus, and Andreas Bodenstein of Karlstadt. ${ }^{40}$

No severe tensions between Thomists and Scotists seem to have arisen, but from Karlstadt's early works we can trace nuances in the relationships between the schools. As a Thomist, Karlstadt adopted Aquinas's and some later Thomist views, especially that of the $14^{\text {th }}$-century Armandus de Bellovisu, but rejects other views held by some Thomist authors. In his earliest work $D e$ intentionibus, Karlstadt comments on Ockham's view in order to refute it, but at the same time adopts some terminology used by Ockham. ${ }^{41} \mathrm{He}$ also criticizes the Scotist view, directing his criticism particularly towards Pierre Tartaret, whose textbooks were used in Wittenberg. However, his criticism is not as harsh as that directed towards Ockham, and in some cases he considers the differences between the Thomist and Scotist positions as merely terminological, highlighting the commonalities concerning epistolomological issues. ${ }^{42}$ Similar tendencies show up even stronger in Karlstadt's other publication from the same year, the Distinctiones Thomistarum. There he adopts a position, which provides a Thomist reading of the Scotist doctrine of formal distinction, which was 
based on the $15^{\text {th }}$-century Thomist John Capreolus. Nonetheless, the summary at the end of the works reveals that he largely fails in harmonizing the two positions in several respects. ${ }^{43}$

\section{Luther and the Via Moderna}

A specific, positive contribution of Biel and the via moderna in Luther's theology has not been easy to point out. In his earliest surviving works, which date from the time of his theological studies in Erfurt, Luther stayed within the camp of the via moderna, which was not typical for the theologians of the Augustinian order. He exerts harsh criticism on ancient philosophers and on philosophy more generally, but even that was not uncommon among the contemporary theologians of the via moderna. The specific criticism on late medieval authors is directed towards writers like Scotus, and in it Luther does not hesitate to quote Ockham and Peter of Ailly, who count among the main authorities of the via moderna. ${ }^{44}$

Still during his career in Wittenberg, Luther seems to have adopted some of Ockham's readings of Aristotle, shared by Biel, as a part of his criticism of Aristotelian philosophy. ${ }^{45}$ In the later eucharistic disputes against Zwingli, Luther argued against Scotist metaphysical doctrines with arguments found among the via moderna. ${ }^{46}$ Similarly, regarding the terminology used in Trinitarian and Christological discussions, Luther used the terminology of Biel and the authorities of the via moderna throughout his career, even if he also criticized certain positions of the via moderna. ${ }^{47}$

On some specific themes regarding the mostly philosophical discussions, one can trace some continuities between Luther and his scholastic teachers. Yet it would be inappropriate to consider Trutfetter or Arnoldi as sources of Luther's criticism against scholastic theology, as has sometimes been suggested. ${ }^{48}$ However, for the formation of Luther's criticism against Aristotle's psychological 
views, the position of the via moderna in delineating the border between philosophy and theology is not irrelevant. Trutfetter seems to suggest the incompatibility of certain basic doctrines of Aristotle with the immortality of the soul; in other words, he does not clearly affirm that the philosophical arguments presented for the doctrine are convincing. Despite this, he emphatically teaches the doctrine of immortality in his work on natural philosophy, and considers explicitly such a procedure as an implementation of the decrees of the Fifth Lateran Council issued during the previous year of 1513 Regarding this question, Arnoldi follows a more common tradition of the via moderna in Erfurt, which affirms the validity of philosophical proofs for the immortality of the soul, even if not in the strictest sense of philosophical demonstration. ${ }^{49}$

The decisive novelty in Luther's sayings on this theme is not found in his distinction between theology and philosophy or in the affirmation of the doctrine of immortality as a central Christian belief, in which he was in fundamental agreement with his scholastic teachers. In denying the status of substantial form of the human intellectual soul, Luther disagreed with the formulations of his teaching. Nevertheless, this may be taken merely as an indication of a more substantial methodological divergence. While Luther's teachers scrupulously followed the decrees of the Western councils and adapted their philosophical positions to them as best as they could, Luther took the liberty of contradicting the councils. This allowed him to develop his criticism beyond the reluctance against the full-scale philosophical demonstrations of the truths of faith in the via moderna and the faint sceptical tones against Aristotle found in Trutfetter. For Luther the consideration of the human intellectual soul as a substantial form was an unholy concession to Aristotle's overly materialist philosophy. Equally, the later decree of the immortality of the soul was an indication of the depravity of the Church, even if the doctrine itself was acceptable to Luther. Luther's reasoning was that since the Church was compelled to decree the truths that should 
have been elementary for every Christian to believe, this clearly shows the poor state of Christian faith in the Church. ${ }^{50}$

\section{Luther's Criticism of the Via Moderna}

In contrast to more positive influences, Luther's disagreements with Biel and the via moderna have been amply documented. It is typical that while Luther's colleague Karlstadt published a set of theses against his former Thomist authorities, Luther came out with a similar set of his own, which was later labelled "Disputation Against Scholastic Theology" (Disputatio contra scholasticam theologiam). As Leif Grane has shown in his seminal study, the theses grew out of Luther's earlier marginal glosses on Biel's commentary on Sentences, and since Luther's criticism of Biel outnumbered all other individual authors, the disputation could therefore also be called a "Disputation Against Gabriel Biel."

Luther's criticism concerns especially Biel's view of the capability of a natural human person to know good or do good deeds without grace. The majority of Luther's theses in the disputation are directed to one question in Biel's Sentences commentary, which questions whether the human will is able to love God above all by its natural capacities and thus fulfil the commandment of love. Biel answers the question affirmatively, and Luther's attack consists of criticism of Biel's detailed arguments for his position. ${ }^{52}$

At the core of Luther's response to Biel is his conviction that loving God above all, as requested by the divine commandment, involves a commitment of the whole human person. For Biel, such love is specifically an act of the will, but Luther presupposes the lower human passions and corporal actions as being in accord with loving God as well. In particular, for Luther, love of God above all 
would presuppose freedom from all evil concupiscence, which would mean never becoming angry or not having any carnal lusts. On this basis Luther rejects Biel's main thesis, namely that loving God above all would be possible by natural capacities. ${ }^{53}$

Luther also diverges from Biel's and Ockham's concept of grace. For Luther, the grace of God is an “operative Spirit," which by its very nature cannot be present in a person without being active at the same time. For any meritorious act, as the fulfilment of the commandment of loving God above all, the presence of grace is a necessary and sufficient condition. Conversely, without the presence of divine grace, there can be no meritorious act like any act of loving God. On this basis Luther rejects the possible cases presented by Ockham and Biel that God could, by his absolute power, produce in a person an act of friendship towards God without grace or that he could accept the person without justifying grace. For Luther, the presence of grace is not an additional attribute added to certain human acts, but it is rather indispensable for the emergence of such acts in the first place. ${ }^{54}$

On these premises Luther also objects to Biel's manner of distinguishing between the natural and spiritual fulfilment of the precept. According to Luther, law demands a spiritual fulfilment of the Decalogue, and external works of not killing, and so on, are only sinful acts, if they are performed without the grace of God. Presence of grace is therefore essential to any fulfilment of the divine law, including the commandment to love God above all. ${ }^{55}$

In rejecting the possibility of loving God above all, without grace, Luther also dismisses all possibilities of human preparation for receiving grace. The only possible "preparation," according to Luther, is God's eternal predestination. This includes dismissing different ways of removing the obstacles for the work of grace, such as ignorance of true good. Luther clarifies the impossibility of knowing true good naturally by stating that, without grace, humans are always in the state of 
invincible ignorance concerning their salvation, which does not excuse them of their guilt before God. ${ }^{56}$ For this reason, Luther judges Aristotle's Ethics as harmful for theology, since it is committed to a project of knowing good without grace. This leads Luther to further consider Aristotle's philosophy in general as being harmful for theology, including some applications of Aristotelian logic to theological matters. ${ }^{57}$

While Luther's criticism of the via moderna was based on his ideas already present in his earlier Lectures on Romans, he carried it on later in his Heidelberg Disputation and on many later occasions as well. ${ }^{58}$ Nonetheless, he never again explicated it in the same breadth and thoroughness in reference to Biel and his authorities as he had done in the Disputation Against the Scholastic Theology. This is partly due to the evolution of his doctrines on merit, promise, grace, faith, and justification, which developed in an even sharper direction with regard to medieval theological traditions, and not only to the via moderna. ${ }^{59}$

Among the theologians affiliated with the via moderna, John Eck notoriously became one of Luther's main opponents. After the first major confrontation with Luther and Karlstadt in the Leipzig disputation, Eck became involved in several polemical publications against Lutheran authors. The polemic culminated during the Diet of Augsburg, where Eck was leading the commission of Papal theologians, who produced the Confutation of the Augsburg Confession.

John Mair remained equally unconvinced by the new ideas of the Protestant Reformation. He referred to these in a dedicatory letter for one of his theological treatises from 1528. Unlike Eck, Mair was not actively involved in countering them, but in the letter he clearly considered them heretical. Curiously enough, he gave the movement some indirect credit for forcing theologians to focus their argumentation on Scriptural proofs. Mair himself did not radically alter the traditional 
forms of theological discourse, but published new editions of his Sentences commentary as late as $15300^{60}$

In 1518 Luther tried to convince his teachers Usingen and Trutfetter of his new insights, with no success. With reference to them, Luther concluded that: "My theology is like rotten food to the people from Erfurt." ${ }^{61}$ Trutfetter passed away in the following year, and Usingen became an active opponent of the Lutherans, being nominated in the Papal commission during the Diet of Augsburg, and, as mentioned above, wrote a treatise thereafter against Melanchthon's Apology. ${ }^{62}$

\section{Further reading}

Theodor Dieter, "Luther as Late Medieval Theologian," in Oxford Handbook of Martin Luther's Theology, ed. Robert Kolb et al. (Oxford: Oxford University Press, 2014), 31-48.

Graham White, Luther as Nominalist (Helsinki: Luther-Agricola-Society, 1994).

Heiko A. Oberman, The Harvest of Medieval Theology: Gabriel Biel and Late Medieval Nominalism (Cambridge, Mass.: Harvard University Press, 1963).

Maarten J. F. M. Hoenen, "Via Antiqua and Via Moderna in the Fifteenth Century: Doctrinal, Institutional, and Church Political Factors in the Wegestreit," in The Medieval Heritage in Early Modern Metaphysics and Moral Theory, ed. L. Nielsen and R. Friedman (Dordrecht: Kluwer, 2003), 9-36.

Pekka Kärkkäinen, "Martin Luther," in Mediaeval Commentaries on the Sentences of Peter Lombard Vol. 2, ed. Philipp W. Rosemann (Leiden: Brill, 2010), 471-94. 
Sebastian Lalla, Secundum Viam Modernam: Ontologischer Nominalismus bei Bartholomäus Arnoldi von Usingen (Würzburg: Königshausen \& Neumann, 2003).

Leif Grane, Contra Gabrielem: Luthers Auseinandersetzung mit Gabriel Biel in der Disputation Contra Scholasticam Theologiam 1517 (København: Gyldendal, 1962).

\section{Notes}

${ }^{1}$ Maarten J. F. M. Hoenen, "Via Antiqua and Via Moderna in the Fifteenth Century: Doctrinal, Institutional, and Church Political Factors in the Wegestreit," in The Medieval Heritage in Early Modern Metaphysics and Moral Theory, ed. L. Nielsen and R. Friedman (Dordrecht: Kluwer, 2003), 12.

${ }^{2}$ Hoenen, "Via Antiqua and Via Moderna," 20-22.

${ }^{3}$ Hoenen, "Via Antiqua and Via Moderna," 11-12, 19.

${ }^{4}$ Hoenen, "Via Antiqua and Via Moderna," 11-13.

${ }^{5}$ Adolar Zumkeller, Erbsünde, Gnade, Rechtfertigung und Verdienst nach der Lehre der Erfurter Augustinertheologen des Spätmittelalters (Würzburg: Augustinus-Verlag, 1984), 447-52.

${ }^{6}$ Erich Kleineidam, Universitas Studii Erffordensis II (Erfurt: Benno, 1992), 153-57, 211-14.

${ }^{7}$ Sebastian Lalla, Secundum Viam Modernam: Ontologischer Nominalismus bei Bartholomäus Arnoldi von Usingen (Würzburg: Königshausen \& Neumann, 2003), 274-75; Hoenen, "Via Antiqua and Via Moderna."

${ }^{8}$ LW 41:115(WA 50, 600, 30-31).

${ }^{9}$ Pekka Kärkkäinen, "Psychology and the Soul in Late Medieval Erfurt," Vivarium 47 (2009): 42627.

${ }^{10}$ Kärkkäinen, "Psychology and the Soul,” 427. 
${ }^{11}$ Kärkkäinen, "Psychology and the Soul," 428-30.

${ }^{12}$ Gustav Plitt, Jodokus Trutfetter von Eisenach der Lehrer Luthers in seinem Wirken geschildert (Erlangen: A. Deichert, 1876), 11.

${ }^{13}$ Jodocus Trutfetter, Summule totius logice (Erfurt: Wolfgang Schenk, 1501), B1r.

${ }^{14}$ Kärkkäinen, "Psychology and the Soul," 430-32.

${ }^{15}$ Lalla, Secundum Viam Modernam, 277-78.

${ }^{16}$ Lalla, Secundum Viam Modernam, 285-90.

${ }^{17}$ Lalla, Secundum Viam Modernam, 290.

${ }^{18}$ Jun Matsuura, “Einleitung," in Erfurter Annotationen 1509-1510/11, by Martin Luther, ed. Jun Matsuura (Köln: Böhlau, 2009), CXXIII; CXXVII.

${ }^{19}$ Detlef Metz, Gabriel Biel und die Mystik (Stuttgart: Franz Steiner, 2001).

${ }^{20}$ Metz, Gabriel Biel, 2-3.

${ }^{21}$ Heiko A. Oberman, The Harvest of Medieval Theology: Gabriel Biel and Late Medieval Nominalism (Cambridge, Mass.: Harvard University Press, 1963), 122, 130.

${ }^{22}$ Oberman, Harvest, 132-34, 153, 171.

${ }^{23}$ Leif Grane, Contra Gabrielem: Luthers Auseinandersetzung mit Gabriel Biel in der Disputation Contra Scholasticam Theologiam 1517 (København: Gyldendal, 1962), 216; Oberman, Harvest, 154.

${ }^{24}$ Metz, Gabriel Biel, 300-01.

${ }^{25}$ Bartholomaei Arnoldi de Usingen O.S.A. Responsio contra Apologiam Philippi Melanchthonis, ed. Primož Simoniti (Würzburg: Augustinus-Verlag, 1978).

${ }^{26}$ Oberman, Harvest, 179-80.

${ }^{27}$ Graham White, Luther as Nominalist (Helsinki: Luther-Agricola-Society, 1994), 369, 372-74.

${ }^{28}$ Ueli Zahnd, "Terms, Signs, Sacraments: The Correlation between Logic and Theology and the Philosophical Context of Book IV of Mair's Sentences Commentary," in A Companion to the 
Theology of John Mair, ed. John T. Slotemaker and Jeffrey C. Witt (Leiden: Brill, 2015), 247-48, 287.

${ }^{29}$ Zahnd, “Terms, Signs, Sacraments,” 249-50, 253, 258.

${ }^{30}$ Zahnd, “Terms, Signs, Sacraments,” 259-60.

${ }^{31}$ Zahnd, “Terms, Signs, Sacraments,” 267.

${ }^{32}$ Zahnd, “Terms, Signs, Sacraments,” 271, 276.

${ }^{33}$ Zahnd, "Terms, Signs, Sacraments,” 272-73, 279, 281; Pekka Kärkkäinen, "Conscience and Synderesis in John Mair's Philosophical Theology," in A Companion to the Theology of John Mair, ed. John T. Slotemaker and Jeffrey C. Witt (Leiden: Brill, 2015), 185.

${ }^{34}$ Zahnd, “Terms, Signs, Sacraments,” 282-85.

${ }^{35}$ Arno Seifert, Logik zwischen Scholastik und Humanismus (München: Wilhelm Fink, 1978), 17, $19-21$.

${ }^{36}$ Seifert, Logik, 21-22.

${ }^{37}$ Seifert, Logik, 34-35.

${ }^{38}$ Seifert, Logik, 62.

${ }^{39}$ Heinz Scheible, "Die philosophische Fakultät der Universität Wittenberg von der Gründung bis zur Vertreibung der Philippisten," Archiv für Reformationsgeschichte 98 (2007): 12.

${ }^{40}$ Harald Bollbuck, "Einleitung," in De intentionibus, Karlstadt, in Kritische Gesamtausgabe der Schriften und Briefe Andreas Bodensteins von Karlstadt, Teil I (1507-1518), ed. Thomas Kaufmann (Wolfenbüttel, 2012), http://diglib.hab.de/edoc/ed000216/start.htm

${ }^{41}$ Bollbuck, "Einleitung (De intentionibus)."

${ }^{42}$ Bollbuck, "Einleitung (De intentionibus)."

${ }^{43}$ Harald Bollbuck, "Einleitung" in Distinctiones Thomistarum, Karlstadt, in Kritische

Gesamtausgabe der Schriften und Briefe Andreas Bodensteins von Karlstadt, Teil I (1507-1518), ed. Thomas Kaufmann (Wolfenbüttel, 2012), http://diglib.hab.de/edoc/ed000216/start.htm; Daniel 
Bolliger Infiniti Contemplatio: Grundzüge der Scotus- und Scotismusrezeption im Werk Huldych Zwinglis (Leiden: Brill, 2003), 361-62.

${ }^{44}$ Pekka Kärkkäinen, "Martin Luther," in Mediaeval Commentaries on the Sentences of Peter Lombard Vol. 2, ed. Philipp W. Rosemann (Leiden: Brill, 2010), 475-77, 483, 492; “Augustinian, Humanist or What? Martin Luther's Marginal Notes on Augustine” (forthcoming).

${ }^{45}$ Theodor Dieter, Der junge Luther und Aristoteles: Eine historisch-systematische Untersuchung zum Verhältnis von Theologie und Philosophie (Berlin: Walter de Gruyter, 2001), 343, 630.

${ }^{46}$ Bolliger, Infiniti Contemplatio, 426-31.

${ }^{47}$ White, Luther as Nominalist, 130, 347.

${ }^{48}$ Lalla, Secundum Viam Modernam, 264-65.

${ }^{49}$ Pekka Kärkkäinen, "Nominalist Psychology and the Limits of Canon Law in Late Medieval Erfurt," in Lutheran Reformation and the Law, ed. Virpi Mäkinen (Leiden: Brill, 2006), 103-07; Ibid. "Theology, Philosophy, and Immortality of the Soul in the Late Via Moderna of Erfurt," in Vivarium 43 (2005): 352, 359.

${ }^{50}$ Kärkkäinen, "Nominalist Psychology," 107-08.

${ }^{51}$ Grane, Contra Gabrielem, 42-44, 348-68.

${ }^{52}$ Grane, Contra Gabrielem, 47; Theodor Dieter, "Luther as Late Medieval Theologian," in Oxford Handbook of Martin Luther's Theology, ed. Robert Kolb et al. (Oxford: Oxford University Press, 2014), 36 .

${ }^{53}$ Dieter, "Luther as Late Medieval Theologian," 36-37.

${ }^{54}$ Grane, Contra Gabrielem, 373.

${ }^{55}$ Grane, Contra Gabrielem, 373-74.

${ }^{56}$ Grane, Contra Gabrielem, 372.

${ }^{57}$ Leif Grane, Modus loquendi Theologicus 1515-1518 (Leiden: Brill, 1975), 133-34.

${ }^{58}$ Grane, Modus loquendi. 
${ }^{59}$ For Luther's opposition to Thomism of Cajetan, see Grane, Modus loquendi, 161-91.

${ }^{60}$ James K. Farge, "John Mair: A Historical Introduction," in A Companion to the Theology of John Mair, ed. John T. Slotemaker and Jeffrey C. Witt (Leiden: Brill, 2015), 21.

${ }^{61}$ LW 41:61-62 (WABr 1, 173, 29).

${ }^{62}$ Lalla, Secundum Viam Modernam, 20-22. 